Nadwa : Jurnal Pendidikan Islam

Vol. 13, No.2 (2019)

Accredited by Ristekdikti based on Decree No. 51/E/KPT/2017

DOI: 10.21580/nw.2019.13.2.4918

\title{
Transcendence and Immanence: \\ Teacher Professionalism in Islamic Religious Perspectives
}

\author{
Soufian Hady \\ STIT Kendal \\ soufianhady6658@gmail.com
}

\begin{abstract}
The purpose of this research is to describe what is essence of professionalism teacher in Islamic perspective. This research uses library research. The results showed that the professionalism of teachers in Islam is based on two basic criteria, namely a call of life (Abdullah; transcendence) and expertise (khalifatullah; immanence). Therefore, the Professional teachers in Islam have the dual task of being carriers of religious (trancendence) and scientific missions (immanence). The professional teacher's first mission is to convey the da'wah and values of religious teachings to students, so that their lives are in accordance with religious norms and all their actions are purely for God. While the second mission (immanence) of a teacher is to bring students into intelligent students and master the latest knowledge in accordance with student interests. Hopefully this article can be the spirit of future teacher professional development such as the implementation of Teacher Professional Education (PPG)
\end{abstract}

Keywords: transcendence; immanence: teacher professionalism; Islamic religious; Teacher Professional Education; TPE

\begin{abstract}
Abstrak
Tujuan penelitian ini adalah untuk mendeskripsikan esensi profesionalisme dalam perspektif Islam. Metode penelitian menggunakan studi kepustakaan. Hasil penelitian menunjukkan bahwa profesionalisme guru dalam Islam pada dasarnya didasarkan pada dua kriteria dasar, yaitu panggilan hidup (transendensi Abdillah) dan keahlian (khalifatullah immanence). Oleh karena itu, para guru profesional dalam Islam memiliki tugas ganda yaitu menjadi pembawa misi keagamaan (trancendence) dan misi ilmiah (imanensi). Misi pertama guru profesional adalah untuk menyampaikan dakwah dan nilai-nilai ajaran agama kepada siswa, sehingga siswa dapat menjalani kehidupan mereka sesuai dengan norma-norma agama dan memiliki kesadaran bahwa semua tindakan mereka layak ibadah murni hanya untuk Tuhan mereka. Sedangkan misi kedua (imanensi) seorang guru adalah membawa siswa menjadi siswa yang cerdas dan menguasai pengetahuan terbaru sesuai dengan minat siswa.

Kiranya hal ini bisa menjadi semangat pengembangan profesi guru mendatang seperti pelaksanaan Pendidikan Profesi Guru (PPG).
\end{abstract}

Keywords: transendensi; imanensi: profesionalisme guru; agam Islam; Pendidikan Profesi Guru (PPG)

ISSN 1979-1739 (P) ; ISSN 2502-8057 (E).

(C) 2019 Nadwa : Jurnal Pendidikan Islam | UIN Walisongo.

Accredited by Ristekdikti based on Decree No. 51/E/KPT/2017

http://journal.walisongo.ac.id/index.php/nadwa 
206 | Soufian Hady

\section{Preliminary}

The primordial educational story is contained in a fragment of the dialogue of the creation of the first man, Adam. This education arose because of Adam's motivation and God's will as a direct educator to teach several names. This is explained in the Qur'an Surah al-Baqarah verse 31. Which means: "And He taught Adam the names - all of them. Then He showed them to the angels and said, "Inform Me of the names of these, if you are truthful."

Education is an important part of human life. Education is a system that contains aspects of vision, mission, goals, curriculum, teaching materials, educators, students, infrastructure, and the environment. These aspects are interrelated to form a system. One factor that is very influential on the success of education is the teacher.

The teacher's task is not limited to standing in front of students for hours only to transfer knowledge to students, but the teacher also acts as a figure to be heard (digugu) and imitated (ditiru) by students in all aspects of life. The presence of a teacher influences student psychology so that the real meaning of the teacher is on personification, which can be a real example of personality for students. Personification that cannot be replaced by mechanistic technology, especially on the immanence that is manifested in the divine attitudes of a teacher such as the attitude of responsibility, patience, honesty, optimism and devotion. On the other hand, a teacher also acts as a servant of Allah and khalifatullah whose duty is to convey the truth, so that a high transcendence ability is required in order to have strong principles. Manifestation of transcendence and immanence of God as a human creator is manifested in the figure of a teacher who has a height of faith and noble 
character. 1

Educators have a very large contribution to the intellectual, spiritual, and emotional maturity of students. 2 the teacher component is very important, as a person who is responsible for educating the lives of students, responsible for all attitudes, behaviors and actions in order to foster students to become capable people of good morals, useful for the country.

The important role of the teacher requires that the teacher has special expertise. This needs to be emphasized, considering that many people work as teachers but do not act and have the character of a professional teacher.

In terms of increasing teacher professionalism, the Indonesian government has made many improvements as required undergraduate diplomas to become a teacher in formal educational institutions from elementary school (SD) to high school (SMA) and equivalent, postgraduate for lecturers at the University.

Although the Government has made a provision for professional teachers as stipulated in the Law on Teachers and Lecturers, but in realizing the professionalism of teachers in the context of the implementation of these rules is still an ongoing problem faced. There are implementation of Teacher

1 Istilah trasenden dan imanen sering digunakan dalam bidang filsafat dan tasawuf untuk menggambarkan kehadiran sifat-sifat ke-Tuhan-an dalam diri makhluk-Nya yang menjadikan makhluknya dapat berperan sesuai dengan tujuan penciptaan-Nya. Vakili, Hadi. "Fuzzy Epistemology From View Point of Mystical Theology." Kanz Philosophia: A Journal for Islamic Philosophy and Mysticism 2.1 (2012): 27-44. Dimana dalam Islam penciptaan manusia dalam rangka mengabdi dan menjadi khalifah yang berakhlaqul karimah.

2 Moh. Uzer Usman, Menjadi Guru Profesional, (Bandung: Remaja Rosda Karya, 2002) hal. 16-20 
Professional Education and Training (TPET/PLPG), In Positions up to Pre-Position Teacher Professional Education (PPG), or in the practice of learning in schools.

Professionalism comes from the word profession. Mc Cully defines the profession as "a vocation in which professed knowledge of some departments of learning or science is used in its application to the affairs of others or in the practice of an art founded upon it". This implies that in a professional job always based on intellectual / education in special study programs to be able to benefit others.

Law of the Republic of Indonesia No. 14 of 2005 concerning teachers and lecturers states that teachers are 'Professional educators with the main task of educating, teaching, guiding, directing, training, evaluating, and evaluating students in the formal education pathways for early childhood education, basic education and secondary education'. 3

Thus, professional is work or activities carried out by someone and become a source of income for life that requires expertise or skills that meet certain quality standards or norms and require professional education. 4

As for the characteristics of the profession, Achmad Sunasi stated that there are several main features of the opinion profession, namely: First, the job has a function and social significance because it requires community service. Second, the profession demands certain skills acquired through intensive education and carried out in certain institutions that can be accounted for. This process of acquiring skills is not only

3 Undang-undang Republik Indonesia nomor 14 tahun 2005

4 Arif Rohman, "pendidik dan peserta didik", dalam Dwi Siswono dkk (ed,) Ilmu Pendidikan, (Jogjakarta: UNY Press, 2007), hal. 123 
routine, but also problem solving. So, in a profession, independent judgment plays a role in making decisions not just carrying out tasks. Third, the profession is supported by a scientific discipline (a systematic body of knowledge), not just fragments or just common sense. Fourth, there is a code of ethics that guides the behavior of its members along with clear and strict sanctions against violators of the code of ethics. Supervision of the implementation of the code of conduct is carried out by professional organizations. Fifth, as a consequence of the services provided to the community, members of the profession both individually and in groups receive financial or material rewards.

Sutisna, concluded that the ideal profession had the following elements: first, the mastery of Systematic Theory. Theory is a system of principles and abstract propositions that generally describe the types of phenomena that are the center of attention of the profession. For a professional, theory serves as both a tool and a practice guide. Second, have professional authority. Intensive education in a field of science makes a person have a certain type of knowledge that is the basis for his professional authority according to the field of expertise occupied. Third, there is legal protection and sanctions. Each professional group seeks to strengthen the authority of the community by granting certain powers and special rights both formal and informal. Professional education must meet the quality criteria of education that have met the standards requested by the accreditation body of professional organizations. Fourth, have a professional code of ethics. The ideal profession describes a group whose members have motivation and attitudes that always think and help others. The code of ethics strongly emphasizes community service, professionalism and the goodness of its clients and rejects the 
misuse of professional skills for personal purposes. Fifth, the existence of a professional culture. Professional culture consists of values, norms, symbols, and career concepts. The most important of these values is that essential values are the core services delivered by professional groups to the community. Sixth, having a professional union (organization). A profession is more than a group of authorized individuals, because a profession as a whole has a responsibility for the quality of its unique, tangible, and essential social services. Such responsibilities can be imposed only if the profession has a form of organization, including a mechanism for formulating policies that compel its members to comply.

\section{Unity of Transcendence and Immanence: \\ Profile of Teacher Professionalism in Islam}

Professionals in Islam, especially in the field of education, a person must really have adequate educational quality and desires to support his professional duties, and not everyone can do that task. If the task is given to people who are not experts, it will fail, as the Prophet Muhammad said, If a case is given to non-experts then wait for its destruction (HR. Bukhari); in the Qur'an, Allah also says in Surah al-Isra' verse 84 which is: meaning:" Say: Every person does something according to their own circumstances". Then your Lord knows who is truer in his ways".

According to Porter, as quoted by Karl Tan Beng San, professionals who will be able to face global competition in the millennium era have at least five characteristics of skills, namely: first, having basic skills. The basic skills referred to here are the knowledge and skills acquired through education in formal schools. A teacher must have professional and pedagogical qualities that master the substance of his field of 
expertise. This means that professional attitude implies the importance of efforts to continuously improve quality in order to be able to deal with various issues related to the field of expertise contextually. Second, mastering special skills (specialization). Currently the tendency of the world of work will rely on the specialization of workers who have special expertise will be able to survive and compete in the coming century. Nowadays, someone who has the ability to use methodologically is needed to apply his expertise in real life and beyond, as well as design and monitor the development of his field of expertise from time to time. Third, master computer skills. The use of computers has now penetrated the world. Almost all sides of human life are inseparable from the role of the computer. Communication links with the internet, online networks in banking and the business world all use computer equipment including the world of education. Therefore, the figures of the workers needed at this time are those who understand and master computers, both software and hardware. Fourth, mastering communication skills with foreign languages and communicating with professional languages in developing their duties. Fifth, master managerial and leadership skills. A professional, wherever they are, will have the ability to work together, trust each other and be able to set open strategies to accept new ideas, seek, see, and solve problems and collect and analyze data, while increasing personal ability to handle it and not just follow the standard problem-solving procedures practiced in the community. 5

5 Karl Tan Beng San,Peluang danTantangan-tantangan Tenaga (Makalah

Profesional Tingkat Menengah di Asia Pasifik pada Abad ke-21", Seminar) (Palembang : Politeknik Negeri Sri Wijaya.1998) 
Whereas Teacher Professionalism in Islamic Perspective is based on moral values that distinguish good and bad teacher's behavior, which may or may not be carried out while carrying out his professional duties to educate, teach, guide, guide, instruct, train, evaluate, and evaluate. The professionalism of teachers in Islam is basically based on two main criteria, namely a call of life (transcendence of abdullah) and expertise (immanence of khalifatullah). A call to life or dedication and expertise according to Islam must be made because of Allah. This will measure the extent of sincerity in actions. In Islam, any work (including a teacher) must be done professionally as a manifestation of the attitude of truly actualizing divine attributes. profesionalisme, namely giving an affair or job to an expert 'with all his awareness and responsibility. 6

In supporting professionalism, teachers need to have structured principles, namely:

$>$ Administrative Principles

Administrative principles are principles that lead to a process in becoming a professional teacher. In this case, the teacher must have teacher certification, as proof of a condition for academic qualifications, competence, and physical health. In addition, teachers must participate in the development of the teaching profession, through PPG or teacher professional education, where the education is after an under graduate program that prepares students to have jobs with special skills requirements.

6 Ahmad Tafsir, Ilmu Pendidikan dalam Perspektif Islam, (Bandung:

Remaja Rosda Karya, 1992) hal. 113 


\section{> Operational Principles}

Operational principles include the ability of teachers to master technical work to support the achievement of general performance. Islam has given a guide for someone to carry out their duties and functions with awareness of the trustful character (amanah). With the amanah (trustful character) will be able to guide someone to carry out the task very well because it deals with personal responsibility to others and to the Lord.

The hopes and ideals of teacher professionalism in an Islamic perspective, is the formation of a teacher who can be kind, polite, moral and have good spirituality. As Muslich said that, the teacher in the perspective of Islamic educators (teachers) will succeed in carrying out the task well, if he has creative thinking, and integrated and has religious professionalism competence. 7

According to Sulani, teacher competencies include four things, which are syahsiyah requirements (have a good personality), pedagogic, personality, professional, and idofiyah requirements (knowing, understanding, and being responsive to the social environment).

The government is worried that there will be wrong practices in education if the task of educating is carried out by unprofessional teachers. The impact can be in various forms such as students who are less qualified, students who are immoral, or students who are less prepared to face their future. Therefore, the role of professional teachers is very important, especially in directing education to achieve the goals of Islamic

7 Mansur Muslich, Sertifikasi Guru menuju Profesionalisme Pendidikan. (Jakarta: Bumi Aksara, 2007), hal. 9 


\section{4 | Soufian Hady}

education, namely good students who have a moral character.

Professional teachers in Islam have the dual task of being carriers of religious and scientific missions. The mission of religion for a teacher is to convey the da'wah and values of religious teachings to students, so students can live their lives in accordance with religious norms, while the mission of science for a teacher is to convey knowledge in accordance with the times and the latest discoveries. This first mission is more accurately mentioned as a transcendence mission, namely a mission for a teacher to be able to direct students to have an awareness that all their actions are worthy of pure worship only for their Lord. While the second mission is called immanence mission, which is the mission of a teacher to bring students to students who are intelligent and can master the latest knowledge according to students' interests.

The performance of transcendence and immanence as mentioned above are characteristics that are based on Islamic values. Among others are:

$>$ Taqwa, this word comes from the word "Waqo-YaqyWiqoyah" which means to guard, avoid, stay away, fear, and be careful. Thus, taqwa is not just fear, but is also a strength to obey Allah's commands. With this awareness, making the teacher aware and believe in life that there is no way to escape from God, thus encouraging us to always be in the lines that God has set.

$>$ Have a lot of knowledge; Islam requires people to study. Allah is very pleased with his people who like to seek knowledge. Therefore a teacher must increase his knowledge. Because with knowledge people will increase their faith and degrees in front of Allah SWT. As in the word of Allah QS. Al-mujadilah 11 which means: "(58:11) O you who have believed, when you are told," Space 
yourselves "in assemblies, then make space; Allah will make space for you. And when you are told, "Arise," then arise; Allah will raise those who have believed you and those who are given knowledge, by degrees. And Allah is Acquainted with what you do.'

$>$ Fair Fair; Literally, fair means straight and upright, moving from the wrong position to the right position, fair also means balanced (balanced) and equilibrium (equilibrium).

$>$ Authority; An authoritative teacher is described by Allah in the Qur'an, surah Al-Furqon verses 63 and 64 namely: Meaning: "And the servants of the Most Merciful are those who walk over the earth easily, and when the ignorant address them [harshly], they say [words of] peace. And those who spend [part of] the night to their Lord prostrating and standing [in prayer].

$>$ Sincere; Ikhlas means clean, pure, and not mixed with others. While sincerity in terms of sincerity in carrying out a good deed, which is solely because of God. Sincerely said by God in the Qur'an Surah Al-An'am verse 162, which means: "Say," Indeed, my prayer, my rites of sacrifice, my living and my dying are for God, Lord of the worlds."

$>$ Able to plan and evaluate. Planning is a mental work that requires thinking, imagination and the ability to see the future. Thus, a teacher must be able to plan the teaching and learning process well. The teacher who able to do the planning is same with the person carrying out the future. Because a careful planning in a teaching and learning process requires a thought and ability to see the future, which will succeed when the plan is implemented well. Evaluation is a process to measure and determine the value of something. The types of evaluations that can be applied by a teacher in Islamic education are "Formative 
Evaluation, Summative Evaluation, Placement Evaluation, and Diagnostic Evaluation".

$>$ Mastering the Field occupied. Teachers must be proficient in teaching their knowledge, because a teacher lives with his knowledge. Therefore, the obligation of a teacher is to always pursue and increase his knowledge. 8

$>$ Has a Rabbani Purpose. Teachers should have a rabbani purpose, in which everything rests on God and always obeys Him, serves Him, follows His shari'ah, and knows His attributes. If the teacher already has the character of Rabbani, then in all educational activities on his students will become Rabbani too. Meaning in the word of Allah QS. Al-Anfal verse: 2, which means: "The believers are only those who, when Allah is mentioned, their hearts become fearful, and when His verses are recited to them, it increases them in faith; and upon their Lord they rely."(QS.Al-Anfaal verse: 2)

Thus, professionalism in Islam actually has a higher meaning than professionalism in the perspective of the law on teachers and lecturers. It contains the transcendence and immanence that should be realized from the figure of a teacher. The pinnacle of teacher professionalism in Islam is professionalism that contains spiritual essence values based on religious values so that teacher performance is a mirror of sincerity and devotion in freeing human lust.

With this conception of professionalism in an Islamic perspective, it is expected that Teacher Professional Education (TPE / PPG) both in office and in pre-service positions can bring spiritual moral values in the curriculum being taught. So

8 Zakiah Daradjat, Ilmu Pendidikan Islam,(Jakarta: Bumi Aksara, 2008) hal. 34 
that it can be expected that the output of the teacher's professional education will truly be able to realize teachers of professional quality, pedagogy and spiritual, transcendent and immanent.

\section{Conclusion}

Professionalism in Islam rests on two main criteria, which are life awareness (transcendence) and expertise (immanence). Life consciousness or dedication / responsibility along with its inherited characteristics and expertise that according to Islam must be done because of Allah. This will measure the extent of sincerity, submission and authority. Teachers in Islam as holders of professional and spiritual positions carry a dual mission at the same time, namely the mission of religion (transcendence) and the mission of science (immanence).

\section{References}

Daradjat, Zakiah, Ilmu Pendidikan Islam,(Jakarta: Bumi Aksara, 2008.

Hadi. Vakili, "Fuzzy Epistemology From View Point of Mystical Theology." Kanz Philosophia: A Journal for Islamic Philosophy and Mysticism 2.1 (2012): 27-44.

Hanafi, Imam, Hasbullah Hasbullah, and Yusuf Ahmad. "BASIS TEOLOGIS UNTUK PLURALISME BERAGAMA;

Menimbang Pandangan Kaum Sufi dalam Memahami

Tuhan." TOLERANSI: Media Ilmiah Komunikasi Umat

Beragama 8.1 (2017): 19-42

Muslich Mansur, Sertifikasi Guru menuju Profesionalisme

Pendidikan. Jakarta: Bumi Aksara, 2007.

Nata, Abuddin Ilmu Pendidikan Islam.( Jakarta: Kencana Prenada Media Group. 2010. 
218 | Soufian Hady

Rohman, Arif, "pendidik dan peserta didik", dalam Dwi Siswono dkk (ed,) Ilmu Pendidikan, Yogjakarta: UNY Press, 2007.

Roqib. Moh. . Ilmu Pendidikan Islam Pengembangan Pendidikan Intregatif di Sekolah, Keluarga, dan Masyarakat, Yogyakarta: LkiS 2009

San, Karl Tan Beng, Peluang danTantangan-tantangan Tenaga Profesional Tingkat Menengah di Asia Pasifik pada Abad ke-21", Makalah Seminar Palembang : Politeknik Negeri Sri Wijaya.1998.

Tafsir, Ahmad, Ilmu Pendidikan dalam Perspektif Islam, Bandung: Remaja Rosda Karya, 1992.

Undang-undang Republik Indonesia nomor 14 tahun 2005 Usman, Moh. Uzer, Menjadi Guru Profesional, Bandung: Remaja Rosda Karya, 2002. 